\title{
ЭТИЧЕСКОЕ РЕГУЛИРОВАНИЕ В ВЫСШЕМ УЧЕБНОМ ЗАВЕДЕНИИ И УСЛОВИЯ ЕГО ЭФФЕКТИВНОСТИ
}

\begin{abstract}
Аннотация. В последнее время в США, странах Западной Европы и России всё большую популярность набирает этический кодекс и этическое регулирование в высших учебных заведениях. При этом структура и организация этического регулирования чётко не определена, некоторые исследователи и вовсе лишают этическое регулирование самого эпитета «этическое». Природа этого явления отнюдь не однозначна.
\end{abstract}

Ключевъе слова: Философия, кодекс, университет, регулирование, этика, профессиональная, корпоративная, сотрliance, ВУЗ, управление.

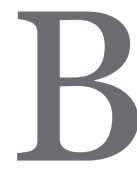

последнее время всё большую популярность набирает этический кодекс и этическое регулирование. Значительная доля профессиональных сообществ и коммерческих компаний уже приняли этический кодекс, крупные корпорации, как правило, внедряют целую систему этического регулирования. Тем не менее, чёткого определения этического кодекса не существует, как не очевидно его положительное влияние на корпоративную культуру компаний и учреждений или на общий уровень нравственности сотрудников. В последние десятилетия XX в. университеты и профильные институты, сначала в англоязычных странах (США, Великобритания, Австралия), затем в Западной Европе и России стали один за другим принимать этические кодексы. Что же такое этический кодекс, и может ли он помочь высшему учебному заведению правильно организовать корпоративную культуру, предотвратить или решить возникающие межличностные конфликты, и, возможно, поднять уважение к нормам морали среди студенчества и преподавателей?

Пролить свет на цели и функции этических кодексов позволит также само понятие кодекс, кодификация. Кодификация, согласно Г.Б. Гутнеру, - особый эффект, порождённый наличием границы габитуса, выражается как «фиксация социальных норм, экспликация (чаще письмен- ная) правил поведения членов сообщества» ${ }^{1}$. (Речь идёт о концепции габитуса, разработанной П. Бурдье, где габитус - неявный принцип порождения практик сообщества, аккумулирующий опыт многих поколений учёных; источник интуиции отдельного учёного и научного сообщества в целом). Бурдье указывает на то, что чем больше стремление к кодификации норм, тем больше риск того, что данные нормы будут проигнорированы. Г.Б. Гутнер пишет, что кодифицированные правила всегда вторичны. Когда определённые практики (этическое поведение, например) заводят в тупик, не работают эффективно, то необходимо рефлексивное отношение к нормам или принципам, их порождающим. Эти принципы нужно представить явно, или записать. Получается, что кодексы лишь экспликация того, что существовало неявно, сами по себе они бесплодны, неспособны порождать практики ${ }^{2}$. Поэтому не стоит возлагать надежд на то, что с помощью кодекса можно сформировать определённые моральные качества в людях, воспитать их; внедрить новые способы регулирования конфликтов без апелляции к административным и законодательным актам. Кодексы осуществляют скорее профилактическое действие. Грубые нарушения трудовой дисциплины или профес-

\footnotetext{
1 Гутнер Г.Б. Социальные практики и габитус научного сообщества // Этос науки / под ред. Л.П. Киященко, Е.3. Мирской. М.: Academia, 2008. С. 341.

2 Там же. С. 341.
} 
сиональных норм караются администрацией, что предусматривается нормативными документами и трудовым соглашением. Этические кодексы запрещают те нарушения, которые, как правило, не подлежат административному наказанию (например, личные оскорбления, сексуальные домогательства, сплетни, слухи, другие формы недостойного поведения). Тем самым они обостряют общественное внимание к этим нарушениям, возбуждают общественное мнение, создают соответствующую атмосферу (нетерпимости или, наоборот, сочувствия), очерчивают границы, рамки свободы индивидуальных решений в данном сообществе. Кодекс, если он действующий, - это инструмент самоорганизации коллектива и культивирования определённых моральных норм: конфликтные ситуации обсуждаются, члены коллектива вынуждены самоопределяться в своем отношении к данному инциденту, в результате либо формируется единое мнение по этому вопросу, либо кристаллизуются различные точки зрения, но в рамках заданных практик и традиций. В соответствии с самим понятием кодекс, можно определить круг задач, которые кодекс выполнить не способен: в первую очередь, это нормотворчество, во вторую, - выделение на первый план тех норм и ценностей, которые исторически не сложились в данном сообществе. Закрепление прав и обязанностей (чаще всего - путём декларирования) - вот неотъемлемые функции кодекса.

Во многом проясняют природу этических кодексов разработки иностранных авторов. Эксперты в области деловой этики, Кэптейн и Шварц (Kaptein M., Schwartz M.S.), говоря об этических кодексах коммерческих корпораций, предлагают и вовсе убрать прилагательное «этический» ${ }^{3}$. Они используют понятие "business code", которое можно перевести как деловой кодекс. Кэптейн и Шварц провели аналитическую работу с целью выявления критериев эффективности этического кодекса и этического регулирования в коммерческих корпорациях, основываясь на 79 экспериментальных исследованиях. Среди исследователей нет единого мнения относительно эффективности кодексов: 35\% признают, что кодексы компаний успешно справляются со своими задачами, 16\% считают, что связь между кодексом и результатами компании довольно слаба, 33\% считают,

\footnotetext{
${ }^{3}$ Kaptein M., Schwarz M.S. The Effectiveness of Business Codes: A Critical Examination of Existing Studies and the Development of an Integrated Research Model. Journal of Business Ethics. 2008.
}

что кодекс не в состоянии оказать значительного влияния на корпоративную жизнь, 14\% дают смешанные результаты. При этом 83\% всех исследований были проведены в США. Исследования, которые авторы взяли в качестве анализируемого материала основывались на разных методах: 1) анкетирование сотрудников компании (даёт наиболее положительные результаты по сравнению с другими методами); 2) интервью с сотрудниками компаний; 3) аналитические методы: а) сравнение компаний имеющих кодекс и не имеющих его по разным критериям; б) сравнение компаний до и после внедрения кодекса; 4) эксперименты / кейсы. В результате анализа существующей литературы по теме этического регулирования, Кэптейн и Шварц приходят к выводу, что эпитет «этический» неуместен по отношению к кодексам компаний, хотя его часто можно встретить. Их определение кодекса выглядит следующим образом: деловой кодекс - это чётко сформулированный официальный документ, содержащий набор предписаний, разработанный в компании и для компании. Кодекс определяет настоящее и будущее поведение руководства компании, её сотрудников по различным вопросам в отношении друг к другу, к компании, к контрагентам и/или к социуму в целом ${ }^{4}$. Кроме того, кодекс лишь тогда может быть назван business code, когда его действие распространяется на всю компанию, а не на отдельные департаменты или профессии, в противном случае - это вспомогательный кодекс (sub-code). Таким образом, деловой кодекс является руководством по поведению в отдельной коммерческой корпорации. Кэптейн и Шварц справедливо убирают эпитет «этический», так как бизнес структуры требуют лишь выполнения определённых правил, то есть соблюдения ритуала, и не призывают придерживаться тех или иных мировоззренческих принципов. Кодекс коммерческих корпораций скорее является инструментом административного управления, а не декларацией этических норм. В своей работе Кэптейн и Шварц приходят к ряду выводов относительно эффективности этических кодексов и исследований этой эффективности. Приведём здесь лишь наиболее интересные выводы, которые помимо кодексов коммерческих

\footnotetext{
4 "A business code is a distinct and formal document containing a set of prescriptions developed by and for company to guide present and future behavior on multiple issues of at least its managers and employees toward one another, the company, external stakeholders and/or society in general. (Там же).
} 


\section{Философия и культура 8(68) • 2013}

корпораций также применимы к кодексам высших учебных заведений. Первые три положения относятся к структуре и текстам кодексов.

1) Авторы утверждают, что в первую очередь следует чётко сформулировать цели кодекса. Если от кодекса ожидается, что он решит все проблемы, такие как повышение репутации компании среди контрагентов / общества в целом / сотрудников компании; контроль над поведением сотрудников и повышение их морального уровня; улучшение психологической атмосферы в коллективе и профилактика внутренних конфликтов и т.д., то он работать не будет. Чем больше будет возлагаться задач на кодекс, тем менее он будет эффективен. Нужно чётко определить основную проблему, которую компания хочет решить с помощью введения кодекса.

2) Кодексы разделяются на три вида в зависимости от того, на какие субъекты распространяется их влияние. Микро-кодекс - это кодекс компании, корпорации, отдельного юридического лица, под его действие попадают сотрудники конкретной компании / высшего учебного заведения / государственной структуры. Мезокодекс - кодекс профессии, отрасли, нации, т.е. охватывает некоторое количество компаний / ВУЗов / корпораций. Макро-кодекс кодексы, разработанные международными институтами и инстанциями, провозглашающие международные стандарты (OOH).

3) Каждый имеет объект воздействия и уровень воздействия. Под объектом понимаются направленность кодекса вовнутрь компании (отношения между сотрудниками компании) или вовне (отношения сотрудников с контрагентами и социумом в целом).

Следующие положения связаны с эффективностью кодексов и критериями их эффективности.

1) Чем больше методов задействовано в исследовании, тем больше будет разброс результатов. Например, метод анкетирования даёт более положительные результаты, а метод сравнения компаний, имеющих кодекс и не имеющих его относительно нарушения законодательства, показывает отсутствие взаимосвязи.

2) Чем меньше критериев оценки эффективности кодекса, тем больше результаты будут отличаться друг от друга

3) Нет более менее значительных различий между компаниями, имеющими кодекс, и компании, которые его не имеют.
4) Поведение топ-менеджеров и руководящего звена влияют на этическое поведение сотрудников.

5) Наличие кодекса не связано со случаями нарушения законодательства сотрудниками компаний.

6) Люди разных профессий по разному воспринимают корпоративный кодекс: студенты дают более негативную оценку кодекса, руководство компании положительно оценивает эффективность кодекса, сотрудники бухгалтерии относятся к кодексу равнодушно и не замечают никаких изменений в поведении коллег после внедрения кодекса.

7) Процедура обсуждения и принятия кодекса сильно влияет на отношение сотрудников к кодексу. Подробное обсуждение проекта с представителями всех подразделений существенно способствует положительному отношению к кодексу, тогда как авторитарное введение кодекса способствует негативному отношению. Процедура принятия кодекса гораздо важнее текста кодекса. "A code is nothing, coding is everything".

8) После принятия кодекса внимание к нему, как правило, затухает и его эффективность сильно понижается.

9) Если положения кодекса не поддерживаются никакими механизмами, это вызывает негативное или презрительное отношение к кодексу. Кодекс приобретает силу когда предусмотрены санкции за его нарушение.

10) Репутация компании не зависит от наличия или отсутствия кодекса (также, каки ВУЗаC.O.).

Таковы характеристики этического кодекса коммерческих компаний. Стоит также учитывать, что сами кодексы порой сильно разнятся по своей структуре или функциям в зависимости от страны происхождения. В обзоре академической литературы с 1987 по 2007 года ${ }^{5}$, утверждается, что этические кодексы США имеют много схожих черт с юридическим правом, а кодексы австралийских компаний более социально ориентированы, гораздо менее походят на свод законов.

Ещё одна характерная черта этических кодексов - уравнивание всех членов сообщества с точки зрения их способности морального сужде-

\footnotetext{
${ }^{5}$ Codes of Conduct in the Private Sector. A Review of the Academic Literature from 1987 to 2007. Carson A.S., Baetz M., McGill S. 2008. P. 10.
} 


\section{Этика}

ния. Общество давно привыкло к тому, что люди не равны интеллектуально и физически, а вот моральное суждение рассматривается как что-то общее для всех, рациональное и независимое от нашей природы. Определяя круг лиц, на которых распространяется действие этического кодекса или кодекса поведения, не нужно рассчитывать на то, что мы имеем дело с взрослыми и рационально действующими личностями. Психиатр, основоположник психоанализа 3. Фрейд первым заговорил о том, что сознание - это всего лишь вершина айсберга. Согласно теории Фрейда скорее общественная мораль наносит вред личности, социум же страдает от личности, больной неврозами, несоизмеримо реже ${ }^{6}$. Последователи Фрейда, психиатры и психологи, занимающиеся личностно-ориентированными методами лечения нервозов, приходят к выводу, что больные часто являются инициаторами конфликтов в семье, рабочем коллективе, распускают слухи, способны на клевету. Самое страшное, что больные нервозами и психически незрелые личности составляют основную массу социума, психически здоровые люди в современном мире почти редкость. В соответствие с концепцией Э. Берна ${ }^{7}$, известного психотерапевта, наше сознание состоит из трёх частей: «Ребёнок», «Взрослый», «Родитель», при этом способность к логическому мышлению и разумным поступкам принадлежит только «Взрослому», а это всего лишь 1/3 нашей психики. Агентом культуры, ритуала, устоявшихся правил (часто нелогичных и глупых с точки зрения психиатров), является «Родитель». К подобным правилам могут относиться: обычаи отмечать дни рождения, Новый год, желание иметь дорогую машину премиум класса, соответствующую социальному статусу и т.д. «Ребёнку» принадлежат наши эмоции и чувства, способность любить, капризничать, радоваться. У личности, нуждающейся в психологической помощи, роль «Взрослого» сведена к минимуму, этот человек почти не воспринимает рациональной аргументации. Ряд известных психологов и психотерапевтов, утверждают, что все конфликты с ближайшим окружением обычно прекращаются после профессионального лечения, и отношения в рабочем коллективе нормализуются.

\footnotetext{
6 Фрейд 3. О психоанализе. Лекции / пер. М.В. Вульф. Минск: Харвест, 2007 (Восемнадцатая лекция. Фиксация на травме. Бессознательное. С. 247-259, Двадцать четвёртая лекция. Повседневные формы нервозности. С. 341-354).

7 Бёрн Э. Игры, в которые играют люди. Люди, которые играют в игры. М.: Эксмо, 2007.
}

Всё вышесказанное поднимает ряд вопросов относительно этического кодекса и этического регулирования. Во-первых, санкции, прописанные в этическом кодексе, не должны быть слишком категоричными и не должны давать ярлыков вроде «аморальная личность», «поступок, недостойный высокого звания студента» и т.д. Раскаявшийся в своём поступке человек, или оступившийся, получив клеймо, лишь обозлиться против этической комиссии в частности и своего ВУЗа. Если допустить в качестве аксиомы, что этический кодекс и этические комиссии и комитеты не должны вмешиваться в дела, попадающие под уголовный и административный кодекс, то сотрудник, нарушивший то или иное положение кодекса, не заслужил клейма. Этический кодекс не должен пересекаться с уголовным и административным ещё и по той причине, чтобы не устраивать лишних заседаний и не присуждать санкций в том случае, когда это излишне. Заседания комиссий и решения, носящие формальный характер не лучшим образом влияют на отношение самих членов комиссии к своей деятельности. Стоит разграничить нормы права и этическое регулирование. Заседание этической комиссии не должно превращаться в суд. Обвинение не должно быть основной функцией этического кодекса прежде всего в российских условиях, в которых сильны авторитарные традиции, и даже университет и академия наук были созданы сверху, в отличие от Западной Европы. Сама возможность ставить клеймо в рамках этического регулирования непременно найдёт, и будет искать (!) себе конкретный объект. Потенциальная энергия в большинстве случаев превращается в кинетическую. Во-вторых, в состав этической комиссии или комитета по этике должен входить практикующий психиатр или психолог. То, что на первый взгляд может показаться аморальным поступком, возможно, является следствием тяжёлых психологических переживаний, провокации и т.д. Также вполне вероятно, что для решения конфликта сторонам нужна психологическая помощь, а непонимание и обиды сторон возникли вследствие неумения общаться.

Теперь, после ознакомления с этическими кодексами вообще, приступим к рассмотрению мнений и исследований, касающихся непосредственно кодексов высших учебных заведений. Как уже упоминалось, в основном кодексы разделяют на профессиональные и корпоративные. Этический кодекс ВУЗа, как правило, тяготеет к одному из этих вариантов. А.А. Скворцов выделил три 


\section{Философия и культура 8(68) • 2013}

основных вида кодексов: 1) профессиональные; 2) корпоративные; 3) кодексы прикладной этики ${ }^{8}$. Этика науки больше выражена в виде деклараций крупных научных сообществ, то есть ближе к профессиональным кодексам. Таков Кодекс научной этики, принятый в 2000-м году Сенатом Общества Макса Планка. Ряд этических кодексов ВУЗов Российской Федерации также ориентирован на профессиональные кодексы: одним из примеров можно считать миссию-кредо Тюменского государственного нефтегазового университета, хотя в тексте самого кредо речь ведётся в основном о научно-образовательной корпорации. Миссия-кредо включает в себя декларацию ценностей профессии учёного, преподавателя. Особенно подчёркивается в миссии-кредо дилемма, - «жизнь в профессии или профессия для жизни», т.е. материального достатка; эту идею развивал ещё Шопенгауэр, обвиняя своих современников в том, что преподавание и написание книг для них является всего лишь заработком9 ${ }^{9}$. Понятия этических кодексов ВУЗов, научных институтов и сообществ, тяготеющих к профессиональным кодексам, такие как «ответственность», «самокритичность» и т.д., как правило, не поясняются, считаются интуитивно понятными. Кодексы научных сообществ (профессиональный кодекс) порицают в основном нарушение прав собственности, фальсификацию данных, препятствование в работе коллег и вводят санкции за нарушения. Термины, такие как плагиат и т.д. подобные кодексы не проясняют, так как считается, что для авторитетных учёных не составит труда дать им трактовку. В последнее время академическая этика находит своё выражение в основном во втором виде кодексов корпоративных кодексах. Они представляют собой не краткие декларации, а брошюры и даже книги, где подробно прописываются нарушения и санкции, перечисляются различные нюансы. Корпоративные кодексы, в отличие от профессиональных, призывают трудиться на благо общего дела, а не доказывать ценность своей профессии. Комиссии по этике, уполномоченные по этике в корпорации, как правило, являются эксперты в области этического регулирования, в сообществе профессионалов - авторитеты, профессионалы высокого класса. Сообщество корпорации ставит перед собой более

\footnotetext{
8 Скворцов А.А. Этическое регулирование в академической среде // Этическое регулирование в академической среде. Материалы международной научно-практической конференции 4-5 декабря 2009 г. М.: Макс-пресс, 2009. С. 63-80.

9 Шопенгауэр А. Об университетской философии // Библиотека Ихтика [электронный ресурс - http://www.ihtika.net].
}

широкие задачи, чем сообщество профессионалов. Последнее обычно прибегает к логике «преступление-наказание», задачи корпорации более сложны: целью выступает не найти виноватого, а найти компромисс. Скворцов А.А. в выборе между корпоративной и профессиональной этикой в отношении к современному академическому сообществу отдаёт предпочтение корпоративной этике, при этом замечает, что в реальности это разделение этических кодексов ВУЗов не имеет чёткой границы. Кроме того, академическая этика имеет ряд особенностей. Во-первых академическая среда носит элитарный характер, ввиду чего очень негативно относится ко всякого рода попыткам регулирования со стороны, будь то государство или международные профессиональные сообщества. Третий вид кодексов - кодексы прикладной этики. Их цель - защита личности, определение её прав. Кодексы прикладной этики исходят из ценности самой личности, регулируют в первую очередь межличностные отношения, тем самым, профессиональные и корпоративные нормы остаются на втором месте. Именно этот вариант этических кодексов, по мнению А.А. Скворцова, и должно принять высшее учебное заведение. Введение кодекса прикладной этики - процесс не быстрый. Прежде всего должна быть проведена аналитическая работа: организованные наблюдательные комиссии изучают мнения сотрудников, межличностные отношения в ВУЗе, выясняют, кому бы из своих коллег или внешних экспертов конкретное академическое сообщество доверило бы разбирать споры и этические проблемы и т.д. Сформированная подобным образом этическая комиссия сможет предугадывать возможные конфликты и, в идеале, предотвращать их.

Другой вариант классификации этических кодексов на той же конференции (5-7 декабря 2009 г.) предложил А.В. Прокофьев. Он выделяет три вида этических кодексов, встречающихся в англоязычных странах, США, Канаде, Великобритании и Австралии: 1) ориентированы на «согласие» compliance; 2) ориентированы на «честность» integrity; 3) смешанная модель. Таким образом, каждый кодекс можно задать точкой на плоскости, координатами по осям compliance, integrity. Первая модель кодексов характеризуется глубокой интегрированностью этического регулирования в административное управление университетом, направлена на поддержания внутриуниверситетской дисциплины. Этот вид кодексов содержит развёрнутое описание прав и обязанностей студентов, преподавателей, других сотрудников 
ВУЗа, подробно прописываются санкции. Особенно отмечаются расширенные полномочия этических комиссий или комитетов, существует подробная регламентация процедур принятия решений внутри этической инфраструктуры. Документация по этическому регулированию, приложения к кодексу, подробные описания прецедентов нарушения этических норм и решения кейсов составляют сотни страниц. Вторая модель характеризуется декларированием принципов и ценностей. Обязанности студентов и преподавателей сформулированы в виде целей индивидуальных действий. Нормативная документация довольно кратка и лаконично сформулирована, санкции не прописываются подробно и остаются на рассмотрение администрации. Деятельность этических комиссий и комитетов часто сводится к консультационной и образовательной работе. Третья модель обычно сочетает в себе ценностные декларации и конкретных норм и санкций, но всё-таки регламентация не является такой подробной, как в первой модели. Эта классификация очень напоминает выше описанное разделение на профессиональные и корпоративные кодексы. Обнаруженное сходство демонстрирует тот факт, что профессиональные кодексы в основном уповают на честность и индивидуальную ответственность (integrity), а корпоративные кодексы на поиски оптимального компромисса между личными целями и целями корпорации, целями других сотрудников (compliance). В основном корпоративные кодексы более детализированы, нежели профессиональные, что также отражено в классификации Прокофьева. Это различие демонстрирует некоторое «недоверие» корпоративного кодекса к сотрудникам корпорации, нежели профессионального кодекса к адептам профессии, хотя в большинстве случаев это одни и те же люди. Корпоративные кодексы ближе к административным нормам, а профессиональные - к нормам морали. В данном случае этические кодексы приоткрывают завесу на тайну самой природы этики. В корпорации больше возможностей для контроля сотрудников, и меньше - в сообществе профессионалов. У ассоциаций профессионалов, принимающей этический кодекс, нет механизмов контроля всех профессионалов, поэтому ассоциации ничего не остаётся кроме того, как взывать к моральному сознанию профессионалов. Отсутствие механизмов контроля или их серьёзное затруднение, - та граница, где заканчиваются возможности административного управления, и где возможно лишь то управление, при котором человек делает свободный выбор в пользу подчинения определённым нормам. Этика становится единственным механизмом управления, если мы имеем дело с большим количеством людей и большими территориями распространения норм. Таким образом, основное различие между профессиональными и корпоративными этическими кодексами - уровень осуществления административного контроля. Плюсы и минусы этического кодекса вида compliance, преимущественно это корпоративный кодекс, в основном такие же, как и у административного управления по отношению к нормам морали. Кодекс compliance позволяет в большей степени контролировать людей, целенаправленно влиять на их поведение путём санкций. Иная природа воздействия кодекса integrity, профессионального кодекса в своей основе. Этот кодекс ближе к моральным нормам, нельзя сказать, что эти нормы воздействует непосредственно на сознание человека, они согласованы с моральным выбором человека (студента, преподавателя и т.д.). Профессиональные нормы, если они являются результатом свободного выбора, - не нуждаются в контроле и санкциях. Проблема лишь в том, что далеко не все люди, задействованные в отрасли, ставят на пьедестал профессиональные нормы нравственности, более того, таких людей всегда меньшинство. Если обраться к специфике научной и философской деятельности, то, несомненно, бросается в глаза творческое начало этой деятельности. Конечно, многим лаборантам, научным сотрудникам, некоторым другим специальностям, задействованным в науке, творческое начало не к чему. Но науку и философию делают именно те, кто сознательно посвящают свою жизнь избранной деятельности. Если выбирать между кодексом compliance (корпоративный кодекс) и кодексом integrity (профессиональный кодекс), то следует выбирать в пользу integrity, - профессионального кодекса этики. Высшим учебным заведениям, без сомнения, нужны и среднестатистические люди, но они не нуждаются в этическом кодексе, который регламентирует их деятельность внутри ВУЗа, для этого достаточно административных правил и устава ВУЗа. От среднестатистических работников требуется в первую очередь ответственность, а нормы, требующие ответственного поведения, включаются, как правило, не только в профессиональный кодекс, но и в устав ВУЗа. Профессиональный кодекс больше соответствует идее университета. Являясь источником информации о ВУЗе, его визитной карточкой, лаконично сформулированный 


\section{Философия и культура 8(68) • 2013}

кодекс может привлечь тех, кто ищет научного и философского идеала - истины, тех, кто мечтает преобразовать мир, помочь человечеству, - идеал, на который должен ориентироваться профильный институт. Место корпоративного кодекса (compliance, code of conduct) в административных документах ВУЗа. При этом администрация ВУЗа должна быть знакома с новейшими разработками в области этического регулирования, социологии и психологии управления. Корпоративный этический кодекс рано или поздно сольётся с административным. Профессиональный кодекс ближе к самой природе моральных норм и должен стать основой этического регулирования, - зеркалом норм, принимаемых добровольно сообществом ВУЗа.

Помимо разделения на три базовые модели Прокофьев выделяет также иные критерии классификации кодексов, относящиеся к структуре текстов кодексов. Первым и наиболее интересным критерием является совмещение или разделение норм, прав и обязанностей для студентов, преподавателей, администрации или других сотрудников ВУЗа в одном документе или нескольких, - для каждой категории университетского сообщества. Такое разделение является аналогом вспомогательного кодекса (sub-code) Кэптейна и Шварца. Следует заметить, что в том случае, когда существует несколько документов этического назначения, эти документы напоминают должностную инструкцию. При такой документации этического регулирования происходит максимальное сближение этического регулирования и управления персоналом в компании. Получается, что этическое регулирование, по сути, становится инструментом администрации по работе с персоналом, носящим этический оттенок. Отдельный этический документ для штатных сотрудников: преподавателей, сотрудников администрации служит не просто напоминанием о своих обязанностях, но и иллюстрирует «идеального сотрудника», т.е. является эталоном, к которому следует стремиться. В том же сообщении «Этическое регулирование в университете» А.В. Прокофьев замечает, что среди широко обсуждаемых международных этических документов, относящихся к деятельности преподавателей и учёных нет ни одной декларации принципов студента. Это и не удивительно: студент из всех членов университетского сообщества наиболее далёк от своей профессии (удалённость от профессионального кодекса) и от работы в корпорации, ВУЗ не является его работодателем (уда- лённость от корпоративного кодекса). Отдельные этические документы - должностные инструкции следует также включить в административную документацию, лучше всего, - как приложения или дополнения к уставу университета.

В зарубежной литературе ${ }^{10}$ представлены в основном практические рекомендации по построению этических кодексов, теоретических разработок меньше. Любопытна классификация кодексов по уровням, приведённая Кэптейном и Шварцем: она вполне подходит и к кодексам ВУЗов. Они разделяют кодексы на микро, мезо и макро-кодексы. Микро-кодекс - регулирует отношения в рамках организации, мезо-кодекс охватывает сообщество профессионалов, как правило, в отдельно взятой стране, макро-кодекс может регулировать целую отрасль. Примером макро-кодекса может служить Бухарестская декларация этических ценностей и принципов высшего образования в Европе ${ }^{11}$. Ориентация кодексов отдельных ВУЗов на макрокодексы даст им возможность соответствовать международным стандартам, создаст единое поле этического регулирования и единые стандарты поведения в ВУЗе.

И всё-таки, несмотря на всё возрастающую популярность этических кодексов, остаются серъёзные сомнения относительно их эффективности: вполне вероятно, что большая часть кодексов - лишь дань моде или PR-ход в деле пропозиционирования ВУЗа во внешней среде. Сомнения относительно эффективности этических кодексов замечаются уже в текстах самих этических кодексов. В США довольно часто в кодексах фигурируют предложения, по сути выражающие надежду на то, что кодекс будет действующим. В разделе кодекса Иллинойского Технологического Института «Как применять кодекс» постоянно встречается фраза “we would like..." - мы бы хотели, чтобы... и далее следует ряд положений, которые должны осуществиться при соблюдении принципов, прописанных в кодексе. В этическом кодексе Университета Южной Каролины провозглашается: «мы создаём этический университет, которым бы мы гордились, и который бы служил ярким примером для людей нашего века и грядущих поколений». Фактически,

\footnotetext{
10 Имеются в виду англоязычные экономически развитые страны - США, Канада, Австралия, Великобритания.

11 Бухарестская декларация этических ценностей и принципов высшего образования в Европе 10 августа 2005 ЮНЕСКО-СЕПЕС, официальный сайт ТюмГУ - http://penh.tsogu. ru/nii/folder.2006-12-18.7122125891/Folder.2008-09-24.1310/ Document.2008-10-10.5222.
} 


\section{Этика}

эти пассажи иллюстрируют желание достичь определённой цели ВУЗа, стремление к осуществлению этой цели, но не поддержание существующего порядка, нет таких оборотов как «у нас принято...» и т.д. И это не удивительно, оба кодекса ещё очень молоды: этический кодекс Университета Южной Каролины принят 28 марта 2004 года, а кодекс Иллинойского Технологического Института ещё ждёт дальнейшего обсуждения, последняя его версия относится к 27 февраля 2007 года. В недавно принятых впервые (а не дополненных или пересмотренных) этических кодексах ВУЗов США формулируется определённая цель или цели, а кодекс преподносится как средство достижения данной цели, при условии, что он будет действующим. Тем не менее, А.В. Прокофьев, активно участвовавший в разработке этического кодекса философского факультета МГУ замечает, что опыт кодификации этических норм в Британии и США не всегда удачен ${ }^{12}$. Следует заметить, что большинство кодексов ВУЗов, в отличие от кодексов коммерческих корпораций, даже в США были введены в 1990-е 2000-е года. При этом принятию кодексов в США и Британии предшествовали дебаты об этических принципах в отдельных отраслях (наука, инженерное дело, журналистика и т.п.), велись разработки в области профессиональной, деловой, корпоративной этики; был образован ряд центров по прикладной этике, таких как американские Ethics Resource Center (центр peсурсов по этической тематике, преимущественно бизнес этике), Center for the Study of Ethics in the Professions при Иллинойском Технологическом институте; английский The Council for Industry and Higher Education, Australian Association for Professional and Applied Ethics и многие другие. Исследования относительно этических кодексов коммерческих корпораций велись на протяжении века за рубежом и в последние годы в России: многие исследователи считают, что кодексы поведения, с чётко прописанными санкциями, напоминающие своды законов, работают значительно эффективней профессиональных кодексов, призывающих соблюдать моральные нормы и чтить профессиональные стандарты. Нынче ВУЗы также обратились к этическому регулированию. Ещё

\footnotetext{
12 Прокофьев А.В. Этический кодекс академического сообщества: параллельный опыт разработки // Ведомости № 34 / под ред. В.И. Бакштановского, Н.Н. Карнаухова; НИИ Прикладной этики, Государственное образовательное учреждение высшего профессионального образования «Тюменский государственный нефтегазовый университет». С. 100.
}

Джон Дьюи писал, что сфера образования - наиболее консервативна и последняя реагирует на тенденции, происходящие в обществе. Вопрос о том, насколько совместим опыт коммерческой среды со спецификой ВУЗов, остаётся открытым. Совет по вопросам высшего образования Великобритании (Council for Industry and Higher Education and Universities UK, CIHE) обратился к руководству ВУЗов с призывом последовать примеру коммерческих корпораций. В обращении, опубликованном в октябре 2005 года 'Этика: управление вопросами этики в системе высшего образования" (Ethics Matter: managing ethical issues in higher education), затрагиваются этические проблемы, возникающие в приёмных комиссиях, касающиеся расовой дискриминации в общежитиях ВУЗов, моральных дилемм и иных ситуаций, требующих морального выбора или этического регулирования. Основная проблема в том, что нет механизмов этического регулирования подобных ситуаций в ВУЗе, ни в одном из этических кодексов английских ВУЗов не прописан порядок действий в подобных ситуациях. Генеральный директор Совета Ричард Браун сообщает в обращении, что обсуждение и написание этического кодекса позволит университетам выйти на более высокий уровень как в управлении ВУЗом, так и внешних отношениях с другими ВУЗами и организациями. Этическое регулирование и этический кодекс в сфере высшего образования - явление довольно новое. Несомненно, этический кодекс ВУЗа перенимает черты и опыт этического кодекса и этического регулирования коммерческих корпораций. Результатов, показывающих благотворное влияние кодекса на ВУЗ, пока совсем мало, а сомнения относительно необходимости кодекса присутствуют не только в студенческой среде, но и среди преподавателей и администрации, что серьёзно тормозит внедрение и развитие этического регулирования. Если такое мнение будет превалировать, то главной функцией кодекса так и останется быть визитной карточкой ВУЗа в худшем понимании этого слова.

Целый ряд зарубежных, преимущественно американских исследователей, сходится на том, что этический кодекс не может быть эффективен и не влияет на этические принципы и представления отдельной личности. В основном их критика направлена на вышеописанные кодексы профессиональной этики (ориентированные на честность, представляющие собой короткие декларации ценностей). Американский исследователь Джон Лэд (John Ladd) видит этический кодекс, как ВУЗа, так и коммерческой 


\section{Философия и культура 8(68) • 2013}

корпорации смешением этики с законом, попыткой возведения моральных норм в закон, что противоречит самой природе этих норм. Он отказывает профессиональной этике в статусе самостоятельной дисциплины, считает, что у представителей той или иной профессии нет особых моральных прав или обязанностей, отличающихся от общечеловеческих. Лэд уверен, что профессионалы способны обходится традиционной теоретической этикой, а моральные дилеммы в отраслях производства (он рассматривал инженерное дело) вполне решаемы общепринятыми моральными нормами, главное, чтобы конкретный сотрудник их придерживался ${ }^{13}$. По мнению Лэда, людям не хватает изучения этических учений и моральности как таковой, нужно культивировать в обществе уважение к общепризнанным нормам нравственности вне зависимости от профессий, и для этого не нужно такой квазидисциплины как прикладная этика. Если общество в целом уважает моральные нормы и юридические законы, сотрудникам компаний не нужно прописывать отдельными пунктами, что нехорошо воровать комплектующие, халатно относиться к работе, продавать некачественный товар под маркой высшего сорта и т.д. С Лэдом солидарен другой американский профессор - Ганс Люгенбайль (Heinz Luegenbiehl). Он замечает, что специалисты редко обращаются к этическому кодексу, ведут себя так, как будто его не существует; он считает, что кодекс не является документом, по которому принимаются решения, но призывом держать в уме определённые принципы, при этом гарантии того, что эти принципы будут восприняты, кодекс дать не в состоянии. Он справедливо замечает, что вряд ли кто последует этим принципам, поскольку в уме человека ничего не изменится после внедрения этического кодекса в организации, где он работает. Кроме того, этический кодекс может входить в конфликт с моральной автономией субъекта ${ }^{14}$, заставляет сотрудника принимать чуждые ему нормы. Получается, что этический кодекс скорее создаёт проблемы, нежели решает их.

Все эти замечания направлены, как нетрудно заметить на кодекс профессиональной этики, взыва-

${ }^{13}$ Ladd J. The Quest for a Code of Professional Ethics: An Intellectual and Moral Confusion // Engineering, Ethics, and the Environment // Aarne P. Vesilind, Alastair S. Gunn // GB: Cambridge University Press, 1998. P. 210-218.

${ }^{14}$ Luegenbiehl, Heinz C. "Codes of Ethics and the Moral Education of Engineers", Business and Professional Ethics Journal 2 (1983); Heinz C. Luegenbiehl: Computer professionals: Moral autonomy and a code of ethics. Journal of Systems and Software 17(1): 61-68 (1992). ющей к моральным чувствам и принципам сотрудников, и почти не затрагивает детализированные кодексы корпораций, основанных на компромиссе compliance (а ведь Кэптейн и Шварц и вовсе отказали кодексам в эпитете «этический»).

В России этические кодексы также подверглись критике уже на этапе разработки и внедрения. Среди российских исследователей высказывается много сомнений относительно своевременности введения кодексов. Специалисты НИИ прикладной этики Тюменского государственного нефтегазового университета В.И. Бакштановский, Н.Н. Карнаухов и другие, разработав миссиюкредо университета, вынесли его на суд коллег с разных уголков нашей страны. Опрос преподавателей философских и не только факультетов показал, что прогнозы относительно этического регулирования в российском ВУЗе отнюдь не оптимистичны. Одной из наиболее неблагоприятных оценок перспективы этического регулирования является позиция Г.Л. Тульчинского ${ }^{15}$. Он считает, что этический кодекс может стать инструментом межличностных разборок среди административно-преподавательского состава, судом чести или процедурой оправдания ряда административных суждений. Дело в том, что в идеале этическое регулирование в ВУЗе должно быть органически встроено в систему управления. На практике ситуация выглядит совершенно по-другому: мы имеем ВУЗ с уже сложившейся системой управления и финансирования, традициями и обычаями. И уже под эту систему подстраиваются механизмы этического регулирования и вводятся этические кодексы. Справедливы опасения, относительно слияния системы этического регулирования с административной системой и превращения первой в карательный механизм второй. В России традиции «административного коммунитаризма» ${ }^{16}$, иерархической системы управления довольно сильны,

\footnotetext{
15 Тульчинский Г.Л., Авторы смело вступили на мало разведанную территорию нравственной культуры университета // Ведомости №34 / под ред. В.И. Бакштановского, Н.Н. Карнаухова, НИИ Прикладной этики, Государственное образовательное учреждение высшего профессионального образования «Тюменский государственный нефтегазовый университет» [электронный ресурс — http://www.tsogu.ru/nii/ethics/. C. 136].

16 Согомонов А.Ю. Для чего современному университету свой этический кодекс? // Ведомости № 34 / под ред. В.И. Бакштановского, Н.Н. Карнаухова; НИИ Прикладной этики, Государственное образовательное учреждение высшего профессионального образования «Тюменский государственныйнефтегазовыйуниверситет» [электронныйресурсhttp://www.tsogu.ru/nii/ethics/. C. 56].
} 
а менталитет, свойственный демократическому режиму, ещё не сложился, если вообще может сложиться. Получается, что без продуманного и плавного изменения самой структуры управления ВУЗа сложно рассуждать о внедрении этических кодексов и механизмов этического регулирования. Другие негативные отзывы, полученные сотрудниками Тюменского государственного нефтегазового университета, также преимущественно опирались на сложившуюся культуру, идущую в разрез с идеалами этического регулирования. О.Б. Томилин критикует проект этического кодекса, предложенного сотрудниками НИИ прикладной этики ТюмНГУ. По его мнению, не были определены внешние условия, - политика государства в области высшего образования, особенности менталитета постсоветского российского общества, традиции административного управления в нашей стране, непонятно, равны ли этически члены общества, почему их равноправие в этическом плане берётся за аксиому, и т.д. С внутренними условиями тоже не всё прозрачно: отношение сотрудников университета к проекту кодекса не однозначно; уровень организационной культуры в отношении внедрения этических кодексов и этического регулирования находится на уровне артефактов (т.е. на уровне видимых процессов: ритуалов, церемоний, стиля одежды и т.д.).

Таким образом, этические кодексы ВУЗов даже не затрагивают в полной мере уровень провозглашаемых ценностей (стратегии развития, цели ВУЗа) и, тем более, уровень базовых представлений (ценности и убеждения, представляемые очевидными). В результате, утверждает Томилин, разработка, внедрение и работа кодекса строится на неопределённых условиях с не совсем определёнными задачами. Судьба такого кодекса - забвение спустя некоторое время после его внедрения. О.Б. Томилин приводит исследования по анализу структуры культуры российского ВУЗа ${ }^{17}$. Основная задача, по мнению О.Б. Томилина, - это интеграция этического регулирования (которое является средством достижения целей ВУЗа, как этических - в первую очередь, так и научно-исследовательских, предпринимательских) в уже существующую систему

\footnotetext{
17 Томилин О.Б. Отцы ели кислый виноград, а у детей на зубах оскомина // Ведомости № 34 / под ред. В.И. Бакштановского, Н.Н. Карнаухова; НИИ Прикладной этики, Государственное образовательное учреждение высшего профессионального образования «Тюменский государственный нефтегазовый университет» [электронный ресурс - http:// www.tsogu.ru/nii/ethics/. C. 126].
}

управления ВУЗом. При удачном внедрении корпоративная структура университета или института должна изменится. Ниже приведена рамочная конструкция конкурирующих ценностей внутри корпоративной культуры предприятия, данная в книге К. Камерона и Р. Куинна «Диагностика и изменение организационной культуры». Н.П. Макаркин, О.Б. Томилин, И.М. Фадеева рассматривают эту модель применительно к учебному заведению ${ }^{18}$. Согласно этой схеме существует четыре базовых типа организационной культуры: иерархическая (бюрократическая), клановая (семейная), адхократическая (или новаторская, характеризующаяся постоянным внедрением инноваций, поиском оптимальных решений), рыночная. Анализ эффективно действующего американского ВУЗа показывает главенство иерархической и адхократической культур; анализ российского ВУЗа - иерархической и рыночной культур. Этот факт косвенно доказывает положение, согласно которому большинство американских кодексов, ориентированных на компромисс между личными целями сотрудников и целями корпорации (compliance) оказывается эффективнее. Детализированный кодекс, сочетающийся суставом ВУЗа, более похожий на административный документ, чем на декларацию ценностей, прекрасно ложится на развитую бюрократическую структуру управления ВУЗом. Без сомнения, большинство членов корпорации попадёт под действие кодекса, что нельзя сказать о кодексе профессиональной этики.

Получается, что почти с гарантией эффективен лишь детализированный корпоративный кодекс, и то только при наличии эффективно действующей административной системы управления. В России построить этическое регулирование, основанное на детализированном кодексе довольно сложно, поскольку, как замечает Томилин, наша традиционная структура управления неразумно регламентирована, находится в условиях нехватки материального обеспечения и финансирования. С другой стороны, даже эффективно действующий этический кодекс больше походит не на свод моральных правил или кодекс чести, а на административные предписания, уставы, законодательные акты. Означает ли это, что этическое регулирование провалилось, ещё не преступив к

\footnotetext{
18 Макаркин Н.П., Томилин О.Б., Фадеева И.М. Опыт стратегического планирования в Мордовском Государственном Университете // Официальный сайт журнала «Университетское управление: практика и анализ» [электронный ресурс http://www.umj.ru/index.php/pub/inside/398/].
} 


\section{Философия и культура 8(68) • 2013}

делу? Ведь административная структура, будучи рационально и грамотно построена, вполне может справиться без этического регулирования. С другой стороны, этический оттенок не помешает администрации, он облагородит и оживит цели системы управления. Даже если этический кодекс оказался не совсем «этическим», это не повод отказываться от этического регулирования в ВУЗах, а начать поиски нового основания для этого регулирования.

\section{Список лuтературь:}

1. Бёрн Э. Игры, в которые играют люди. Люди, которые играют в игры. М.: Эксмо, 2007.

2. Бухарестская декларация этических ценностей и принципов высшего образования в Европе 10 августа 2005 г. ЮНЕСКО-СЕПЕС, официальный сайт ТюмГУ - http://penh.tsogu.ru/nii/ folder.2006-12-18.7122125891/Folder.2008-09-24.1310/Document.2008-10-10.5222.

3. Гутнер Г.Б. Социальные практики и габитус научного сообщества // Этос науки / под ред. Л.П. Киященко, Е.3. Мирской. М.: Academia, 2008. С. 341.

4. Макаркин Н.П., Томилин О.Б., Фадеева И.М. Опыт стратегического планирования в Мордовском Государственном Университете // Официальный сайт журнала «Университетское управление: практика и анализ» [электронный ресурс - http://www.umj.ru/index.php/pub/inside/398/].

5. Прокофьев А.В. Этический кодекс академического сообщества: параллельный опыт разработки // Ведомости № 34 / под ред. В.И. Бакштановского, Н.Н. Карнаухова; НИИ Прикладной этики, Государственное образовательное учреждение высшего профессионального образования «Тюменский государственный нефтегазовый университет» [электронный ресурс - http://www.tsogu. $\mathrm{ru} / \mathrm{nii} / \mathrm{ethics} /]$.

6. Скворцов А.А. Этическое регулирование в академической среде // Этическое регулирование в академической среде. Материалы международной научно-практической конференции 4-5 декабря 2009 г. М.: Макс-пресс, 2009. С. 63-80.

7. Согомонов А.Ю. Для чего современному университету свой этический кодекс? // Ведомости № 34 / под ред. В.И. Бакштановского, Н.Н. Карнаухова; НИИ Прикладной этики, Государственное образовательное учреждение высшего профессионального образования «Тюменский государственный нефтегазовый университет» [электронный ресурс - http://www.tsogu.ru/nii/ethics/].

8. Томилин О.Б. Отцы ели кислый виноград, а у детей на зубах оскомина // Ведомости № 34 / под ред. под ред. В.И. Бакштановского, Н.Н. Карнаухова; НИИ Прикладной этики, Государственное образовательное учреждение высшего профессионального образования «Тюменский государственный нефтегазовый университет» [электронный ресурс - http://www.tsogu.ru/nii/ethics/].

9. Тульчинский Г.Л. Авторы смело вступили на мало разведанную территорию нравственной культуры университета // Ведомости № 34 под ред. под ред. В.И. Бакштановского, Н.Н. Карнаухова; НИИ Прикладной этики, Государственное образовательное учреждение высшего профессионального образования «Тюменский государственный нефтегазовый университет» [электронный ресурс http://www.tsogu.ru/nii/ethics/].

10. Фрейд 3. О психоанализе. Лекции. / Пер. М.В. Вульф. Минск: Харвест, 2007.

11. Шопенгауэр А. Об университетской философии // Библиотека Ихтика [электронный ресурс - http:// www.ihtika.net].

12. Codes of Conduct in the Private Sector. A Review of the Academic Literature from 1987 to 2007. Carson A. S., Baetz M., McGill S. 2008.

13. Kaptein M., Schwarz M.S. The Effectiveness of Business Codes: A Critical Examination of Existing Studies and the Development of an Integrated Research Model. Journal of Business Ethics. 2008.

14. Ladd J. The Quest for a Code of Professional Ethics: An Intellectual and Moral Confusion. // Engineering, Ethics, and the Environment // Aarne P. Vesilind, Alastair S. Gunn // GB: Cambridge University Press, 1998. P. 210-218.

15. Luegenbiehl, Heinz C. «Codes of Ethics and the Moral Education of Engineers», Business and Professional Ethics Journal 2 (1983); Heinz C. Luegenbiehl: Computer professionals: Moral autonomy and a code of ethics. Journal of Systems and Software 17(1): 61-68 (1992). 


\section{References (transliteration):}

1. Bern E. Igry, v kotorye igrayut lyudi. Lyudi, kotorye igrayut v igry. M.: Eksmo, 2007.

2. Buharestskaya deklaraciya eticheskih cennostey i principov vysshego obrazovaniya v Evrope 10 avgusta 2005 g. YuNESKO-SEPES, oficial'nyy sayt TyumGU http://penh.tsogu.ru/nii/folder.2006-12-18.7122125891/ Folder.2008-09-24.1310/Document.2008-10-10.5222.

3. Gutner G.B. Social'nye praktiki i gabitus nauchnogo soobschestva // Etos nauki / Pod red. L.P. Kiyaschenko, E.Z. Mirskoy. M.: Academia, 2008. S. 341.

4. Makarkin N.P., Tomilin O.B., Fadeeva I.M. Opyt strategicheskogo planirovaniya v Mordovskom Gosudarstvennom Universitete // Oficial'nyy sayt zhurnala «Universitetskoe upravlenie: praktika i analiz» [elektronnyy resurs - http://www.umj.ru/index.php/pub/inside/398/].

5. Prokof'ev A.V. Eticheskiy kodeks akademicheskogo soobschestva: parallel'nyy opyt razrabotki // Vedomosti № 34 / pod red. V.I. Bakshtanovskogo, N.N. Karnauhova; NII Prikladnoy etiki, Gosudarstvennoe obrazovatel'noe uchrezhdenie vysshego professional'nogo obrazovaniya «Tyumenskiy gosudarstvennyy neftegazovyy universitet» [elektronnyy resurs — http://www.tsogu.ru/nii/ethics/].

6. Skvorcov A.A. Eticheskoe regulirovanie v akademicheskoy srede // Eticheskoe regulirovanie v akademicheskoy srede. Materialy mezhdunarodnoy nauchno-prakticheskoy konferencii 4-5 dekabrya 2009 g. M.: Maks-press, 2009. S. 63-80.

7. Sogomonov A.Yu. Dlya chego sovremennomu universitetu svoy eticheskiy kodeks? // Vedomosti № 34 / pod red. V.I. Bakshtanovskogo, N.N. Karnauhova; NII Prikladnoy etiki, Gosudarstvennoe obrazovatel'noe uchrezhdenie vysshego professional'nogo obrazovaniya «Tyumenskiy gosudarstvennyy neftegazovyy universitet» [elektronnyy resurs - http://www.tsogu.ru/nii/ethics/].

8. Tomilin O.B. Otcy eli kislyy vinograd, a u detey na zubah oskomina. // Vedomosti № 34 / pod red. V.I. Bakshtanovskogo, N.N. Karnauhova; NII Prikladnoy etiki, Gosudarstvennoe obrazovatel'noe uchrezhdenie vysshego professional'nogo obrazovaniya «Tyumenskiy gosudarstvennyy neftegazovyy universitet» [elektronnyy resurs - http://www.tsogu.ru/nii/ethics/].

9. Tul'chinskiy G.L. Avtory smelo vstupili na malo razvedannuyu territoriyu nravstvennoy kul'tury universiteta // Vedomosti № 34 / pod red. V.I. Bakshtanovskogo, N.N. Karnauhova; NII Prikladnoy etiki, Gosudarstvennoe obrazovatel'noe uchrezhdenie vysshego professional'nogo obrazovaniya «Tyumenskiy gosudarstvennyy neftegazovyy universitet» [elektronnyy resurs - http://www.tsogu.ru/nii/ethics/].

10. Freyd Z. O psihoanalize. Lekcii / Per. M.V. Vul'f. Minsk: Harvest, 2007.

11. Shopengauer A. Ob universitetskoy filosofii // Biblioteka Ihtika [elektronnyy resurs - http://www.ihtika.net].

12. Codes of Conduct in the Private Sector. A Review of the Academic Literature from 1987 to 2007. Carson A.S., Baetz M., McGill S. 2008.

13. Kaptein M., Schwarz M.S. The Effectiveness of Business Codes: A Critical Examination of Existing Studies and the Development of an Integrated Research Model. Journal of Business Ethics. 2008.

14. Ladd J. The Quest for a Code of Professional Ethics: An Intellectual and Moral Confusion. // Engineering, Ethics, and the Environment // Aarne P. Vesilind, Alastair S. Gunn // GB: Cambridge University Press, 1998. P. 210-218.

15. Luegenbiehl, Heinz C. „Codes of Ethics and the Moral Education of Engineers“, Business and Professional Ethics Journal 2 (1983); Heinz C. Luegenbiehl: Computer professionals: Moral autonomy and a code of ethics. Journal of Systems and Software 17(1): 61-68 (1992). 